GLOBAL JOURNAL OF GEOLOGICAL SCIENCES VOL. 17, 2019: 45-52

COPYRIGHT@ BACHUDO SCIENCE CO. LTD PRINTED IN NIGERIA ISSN 1596-6798

45 www.globaliournalseries.com, Email: info@globaljournalseries.com

\title{
THE BASEMENT AND TECTONISM OF THE RIVER JAMA'ARE FLOODPLAIN: DEDUCTION FROM DC RESISTIVITY DATA
}

\author{
M. Z. MOHAMMED
}

(Received 25 May 2016; Revision Accepted 27 June 2016)

\begin{abstract}
The analysis of DC resistivity data of part of the River Jama'are Floodplain, Northeastern Nigeria was carried out with a view to mapping the basement and the subsurface structures. One hundred and six Schlumberger Vertical Electrical Sounding (VES) stations located at the corners of a $225 \times 225 \mathrm{~m}$ square grid network were occupied. The interelectrode spacing $(A B / 2)$ was varied from 1-225m. Results identified four subsurface geologic layers; topsoil, alluvial sand, Chad Formation/weathered column and basement bedrock as undulating and basal unit at different depths. Four major parallel basement depressions suspected to be regional faults striking approximately NW-SE were delineated. This trend correlated with the general trend of the regional structures in the Chad Basin. The isopach maps of the topsoil and alluvial sand mirrored a more recent NE-SW trend that correlated with the Tibesti-Cameroon trough. However, this recent induced tectonics was adjudged significant to hydrogeology in the area.
\end{abstract}

KEYWORDS: Resistivity, floodplain, basement, sounding, tectonics, hydrogeology

\section{INTRODUCTION}

Geological/structural features with hydrogeological significance in semi-arid basins of the sedimentary/basement transitions include unconsolidated/consolidated deposits and narrow, densely fractured zones associated with major faults or folding axes (Medeiros and de Lima, 1989; Seaton and Burbey, 2000). Such basins are structural depressions that are commonly filled with Quaternary to Tertiary unconsolidated sediments (Mon and Vergara, 1987). In a typical basement terrain, troughs/depressions are generally groundwater collecting centres and serve as aquifer units with considerably high groundwater potential due to their considerable thickness, high permeability and storage capacity (Olorunfemi et al, 1999).

Consequent upon this, A DC resistivity data analysis was done to unravel and define the subsurface geological and tectonic settings of part of the River Jama'are Floodplain, Northeastern Nigeria. The study is also intended to assess the influence of the subsurface geological and geologically induced tectonic settings on borehole failure or success in the area.

\section{Description of the Study Area}

The River Jama'are floodplain is in the West Chad Basin, northern side of the Azare - Jama'are highway, about $30 \mathrm{~km}$ West of Azare town in Katagum Local Government Area of Bauchi-State (Fig. 1 \& inset), and confined within longitudes $9^{0} 56^{\prime} 30^{\prime \prime} \mathrm{E}$ and $9^{0} 58^{\prime} 00^{\prime \prime} \mathrm{E}$ and latitudes $11^{\circ} 39^{\prime} 15^{\prime \prime} \mathrm{N}$ and $11^{\circ} 41^{\prime} 15^{\prime \prime} \mathrm{N}$ which approximate the easting and northing values of
$602631.843 \mathrm{mE}$ and $605356.818 \mathrm{mE}$ and 1288367.009 $\mathrm{mN}$ and $1292062.197 \mathrm{mN}$ of the Universal Traverse Mercator (UTM) coordinates of Zone 31 respectively. The study area covers an area extent of about 4.53 Kilometers square (Mohammed, 2007). The study area is located within the southwestern edge of the Chad Basin of Nigeria (Hadejia-Yobe basin), and it belongs to the sedimentary areas of the northeastern Nigeria. The formations found in the study site include the Cretaceous-Tertiary Chad Formation of Pleistocene age (Matheis, 1989), and alluvial deposits that overlie directly the Chad Formation. The river alluvium deposits along the major river- River Jama'are, consists of silts, clays, and sands while the Chad Formation constitutes all Quaternary sediments of lacustrine origin underlying the surface deposits over a vast area in Bauchi Provinces (Carter et al, 1963). Furon (1963) suggested that the Basin was a tectonic cross point between a NESW trending Tibesti-Cameroon trough and a NW-SE trending Air-Chad trough. The tectonic relief pattern of this area may possibly consist of NW-SE trending horsts and grabens with corresponding gentle undulations in sedimentary cover (Schoeneich and Askira, 1990). The study area is relatively flat terrain (average $370 \mathrm{~m}$ a.s.I.), but slopes gently towards the south. A local topographic high is to the Northern edge of the area at Yola settlement. This makes the entire area vulnerable to periodic flooding at the peak of rainy season. Soil type is lateritic on the topographic highs while more productive soils (sandy clay) occur along the downslope of the floodplain. The drainage system is trellis type (FSN, 1978).

M. Z. Mohammed, Department of Earth Sciences, Adekunle Ajasin University, Akungba-Akoko. Nigeria. 


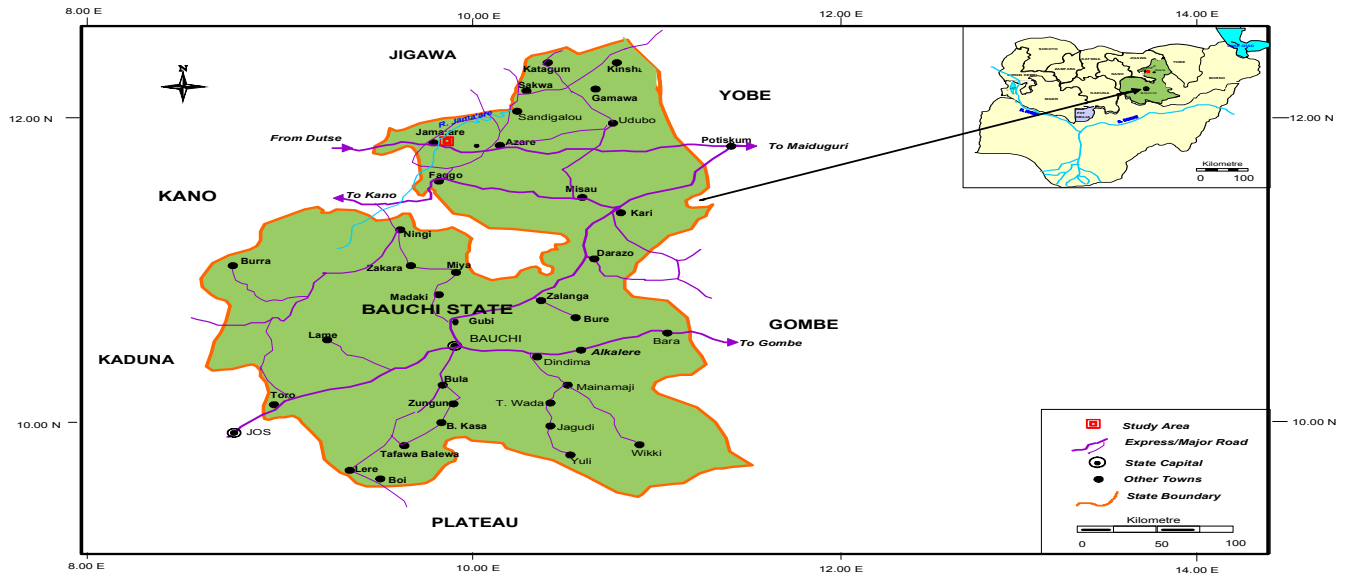

Fig. 1: Map of BauchiState showing the Study Area

\section{METHOD OF STUDY}

One hundred and six (106) Schlumberger vertical electrical resistivity sounding data were collected with PASI-E-Digit Resistivity Meter at the corners of a $225 \mathrm{x}$ $225 \mathrm{~m}$ square grid network (Fig. 2). The inter-electrode spacing $(A B / 2)$ was varied from 1-225 $\mathrm{m}$ with a maximum spread length of $450 \mathrm{~m}$. The data were analysed and presented as depth sounding curve(s) /plot(s) and maps. The curves were interpreted quantitatively by partial curve matching whose results (geoelectric parameters i.e. layer resistivities and thicknesses) were computer iterated with RESIST software (Fig. 3) to obtain satisfactory/final results.

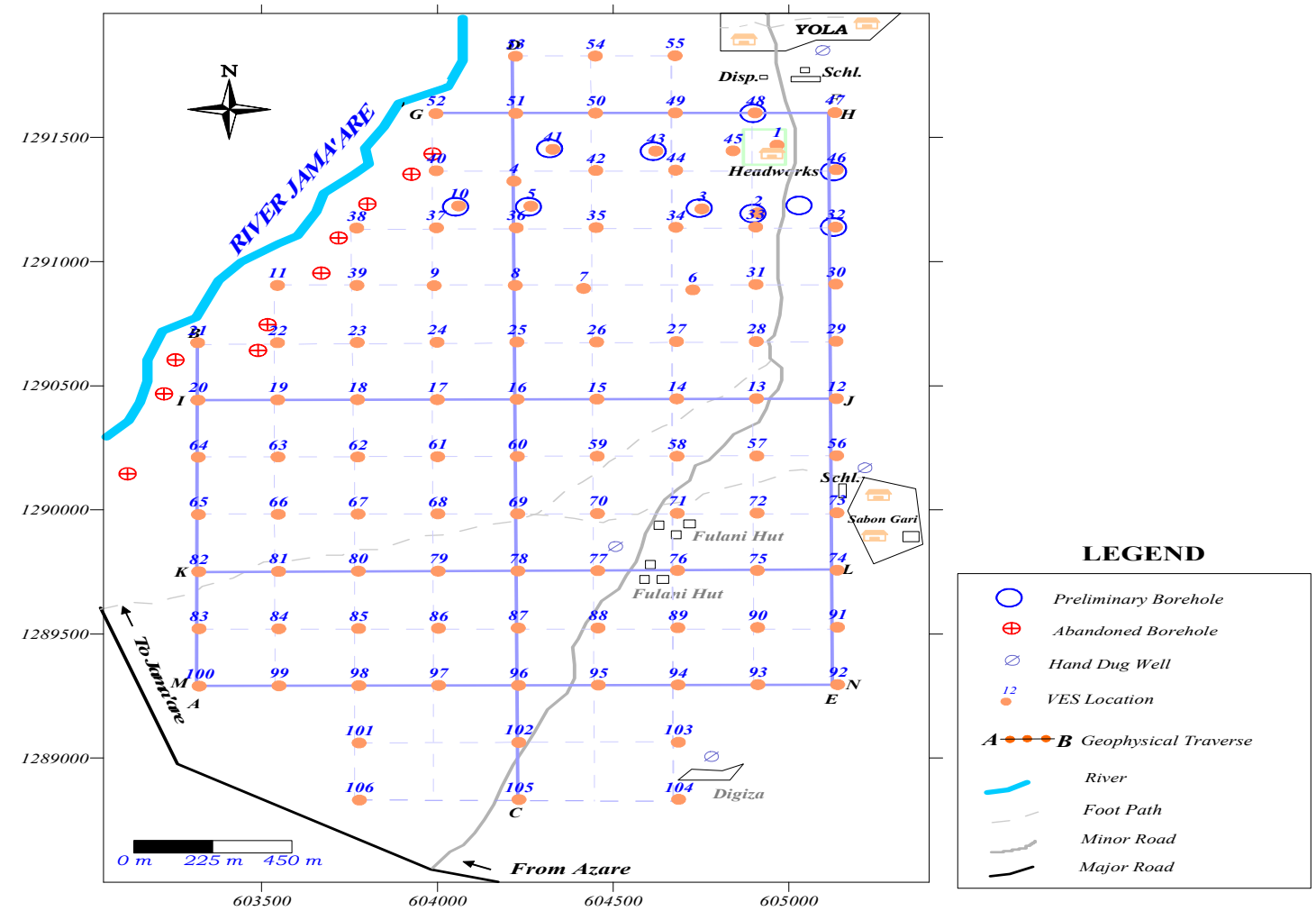

Fig. 2: Geophysical Data Acquisition Map showing VES Stations and Traverses 

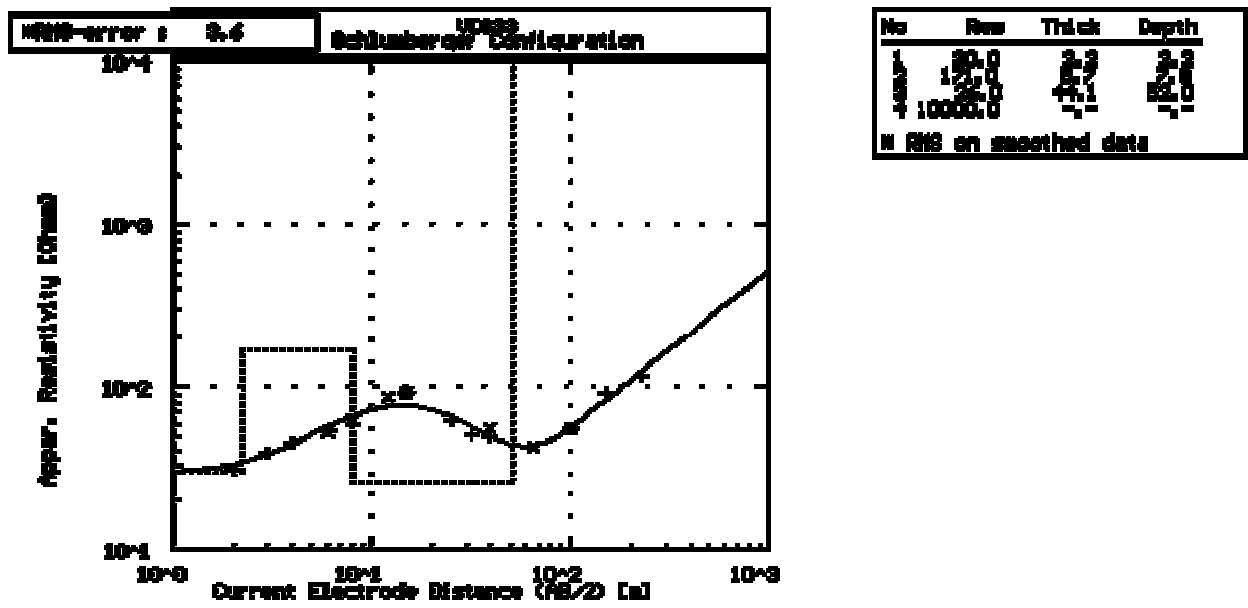

$(\mathrm{KQH})$
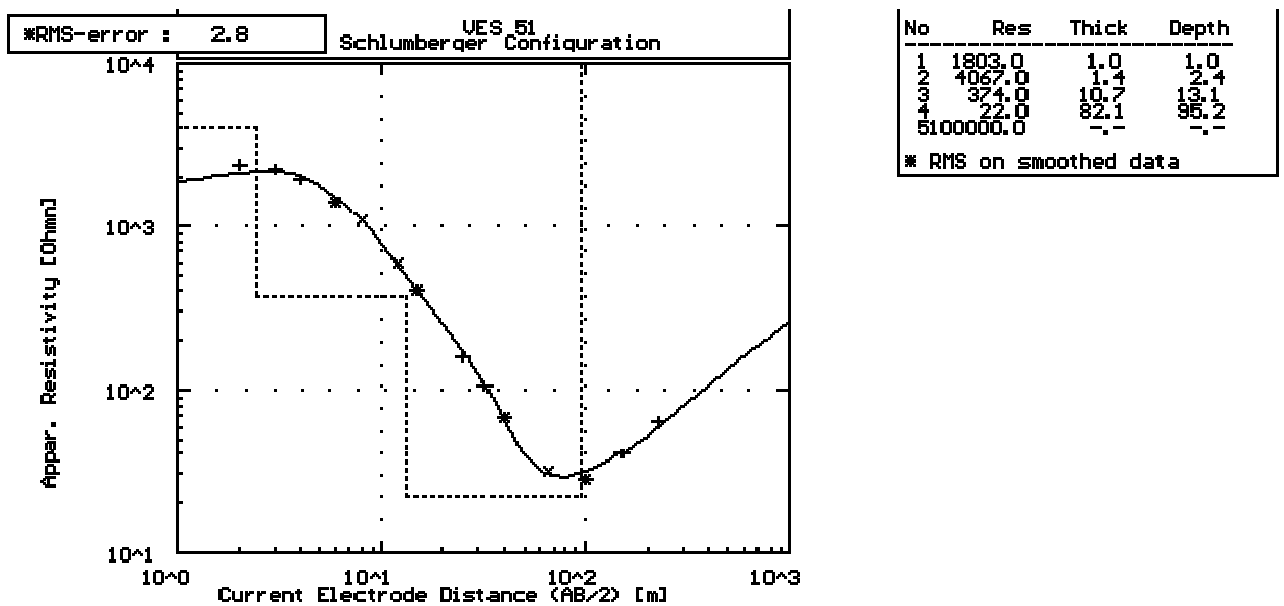

(KHKH)
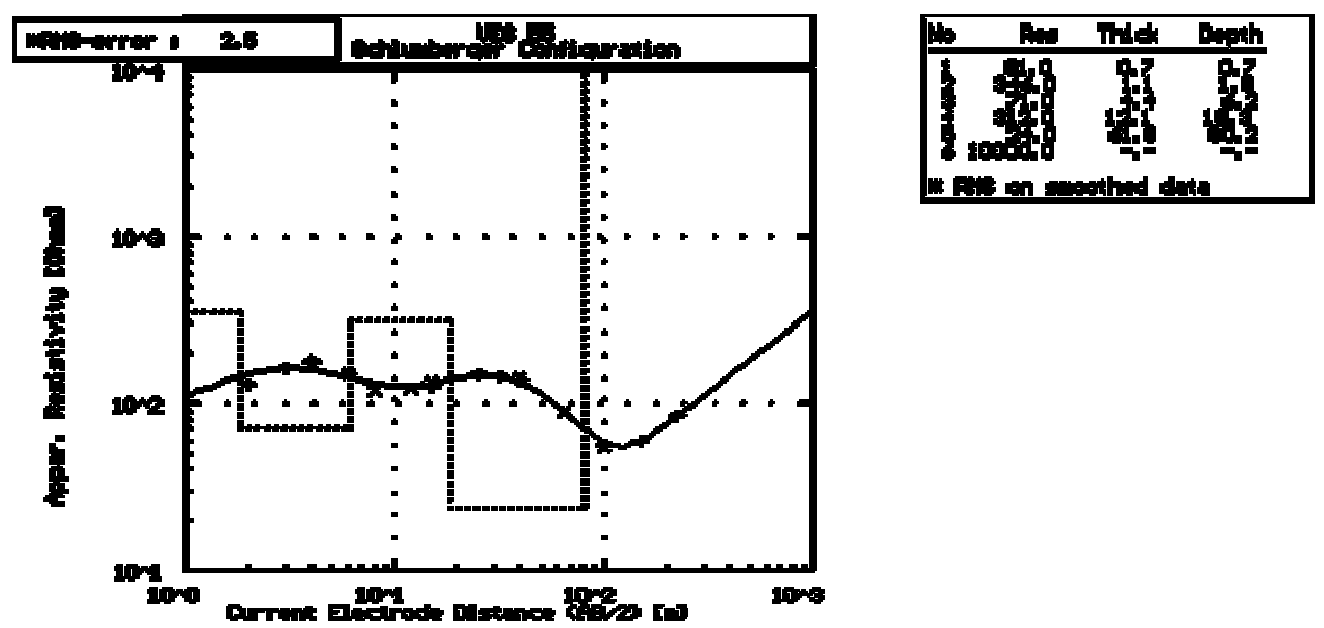

Fig. 3: Computer Interpretation Result of VES Curves

\section{RESULTS AND DISCUSSION}

The geoelectric sections (Fig. 4) display the subsurface sequence and image the basement bedrock relief. The sections show a maximum of four subsurface layers.
The first layer constitutes the topsoil which is composed of dry and loose silty sand, the alluvial sand, clay/sandy clay/Chad Formation/weathered basement column and the fresh basement bedrock. 

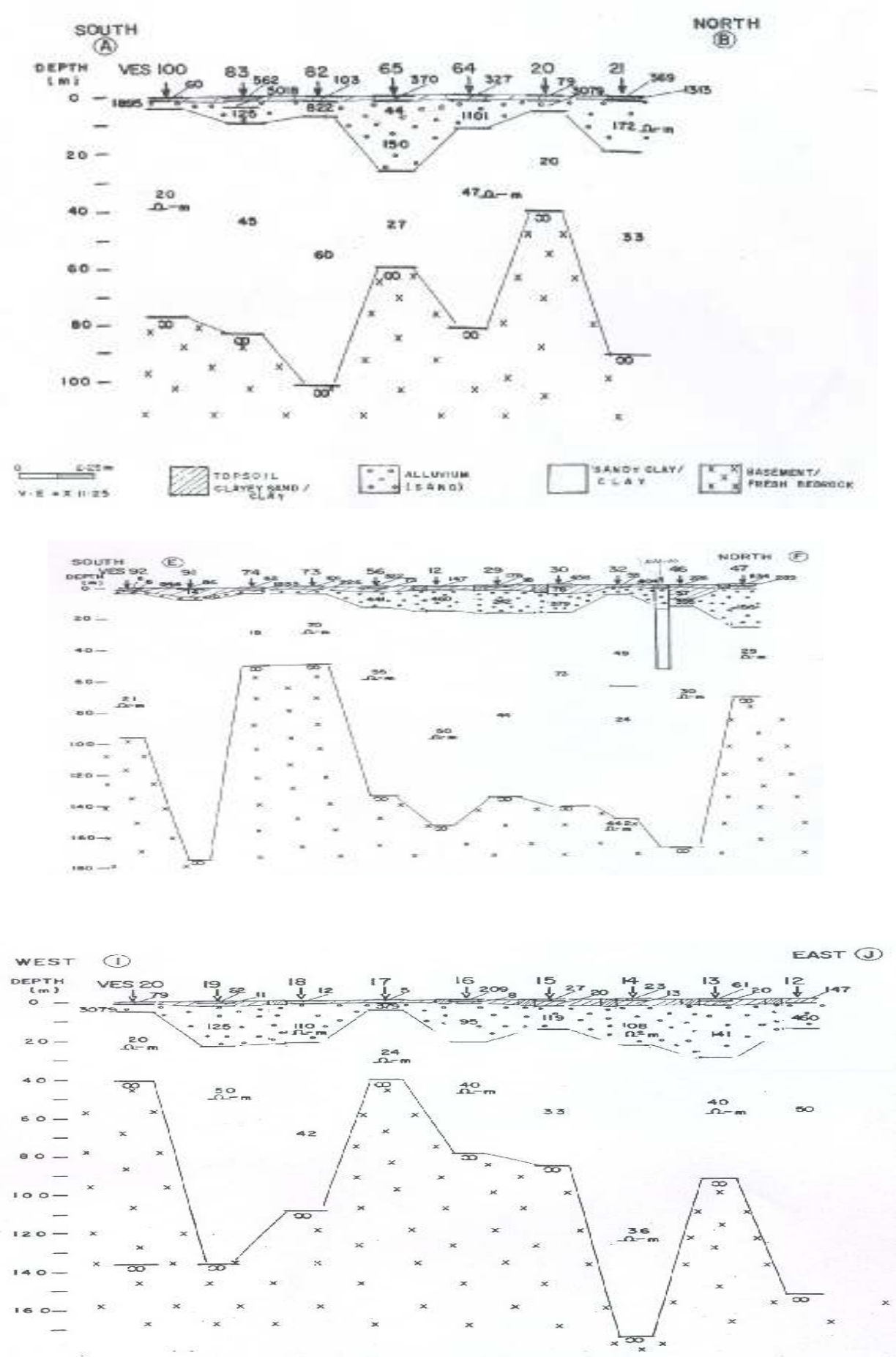

Fig. 4: Some of the Geoelectric Sections along N-S and E-W Traverses

(a) The Topsoil: It has resistivity values most occurring within 0-250 ohm-m. This indicates a wide textural/compositional variation in the topsoil. Typically, the resistivity of this sequence is in the lower hundreds of ohm-m, with resistivity of $<100 \mathrm{ohm}-\mathrm{m}$ typifying clay while the high resistivity (>100 ohm-m) may suggest sandy clay, clayey sand, sand, compact sand or lateritic column (Ako and Olorunfemi, 1989; Olayinka and Olorunfemi, 1992; Olorunfemi and Okhue, 1992 and Omosuyi et al., 2003), as observed in few places, particularly in the topographical high areas in the northern and western edges of the site.From the topsoil resistivity map (Fig. 5), low and high resistivity zones were delineated. More than $60 \%$ of the areal extent displays low resistivity clayey horizons. The closures represent lateritic hardpan or sand. The thickness of the topsoil ranges from 0.4 to $6.7 \mathrm{~m}$, but is generally less than $3 \mathrm{~m}$ with the most frequent values occurring in the 1.0-2.0 $\mathrm{m}$ range. Figure 6 delineates three major parallel thicker portions that mirror a more recent NE-SW trend that correlated with the Tibesti-Cameroon trough. 


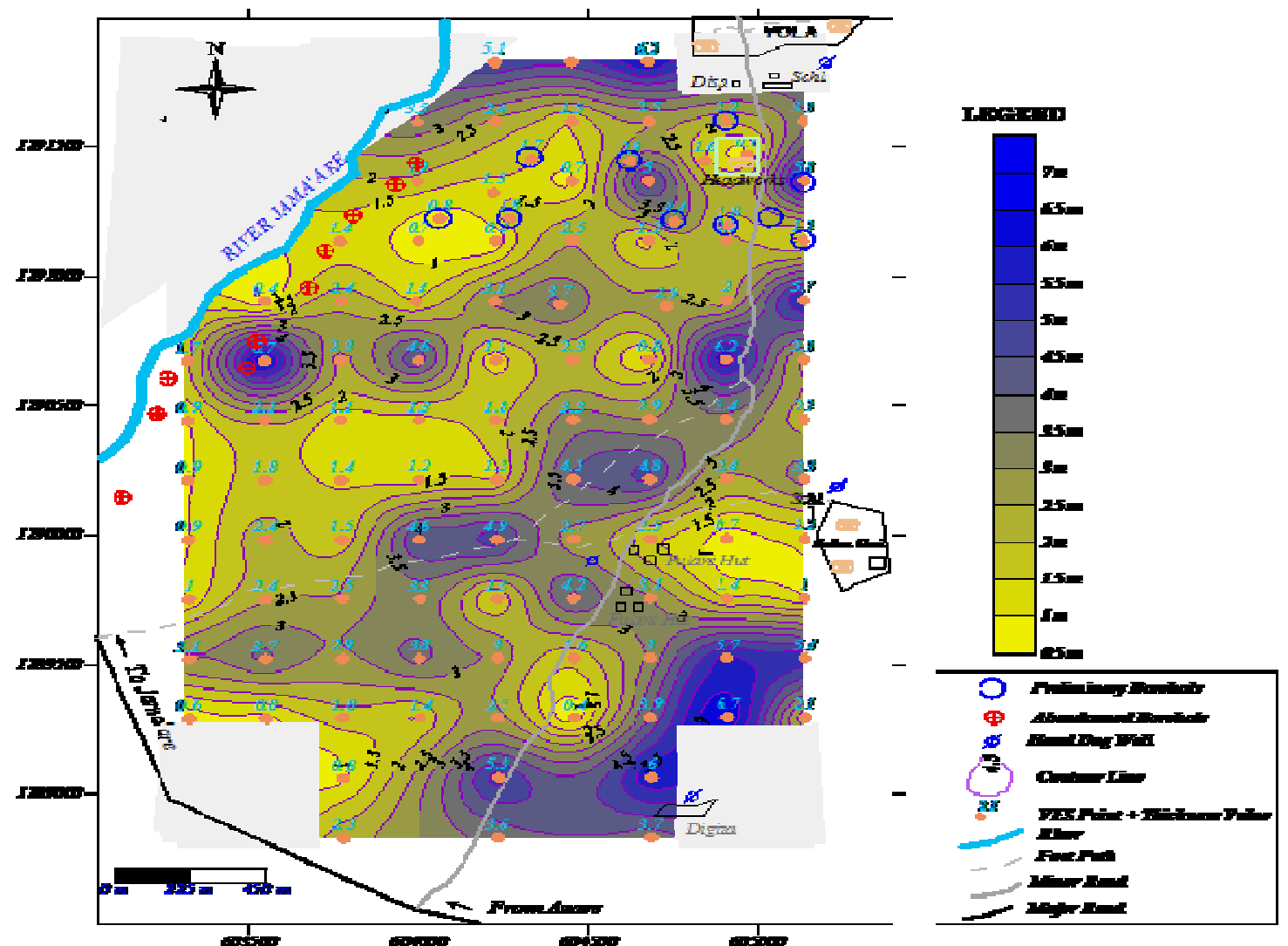

Fig. 5: Isopach Map of the Topsoil
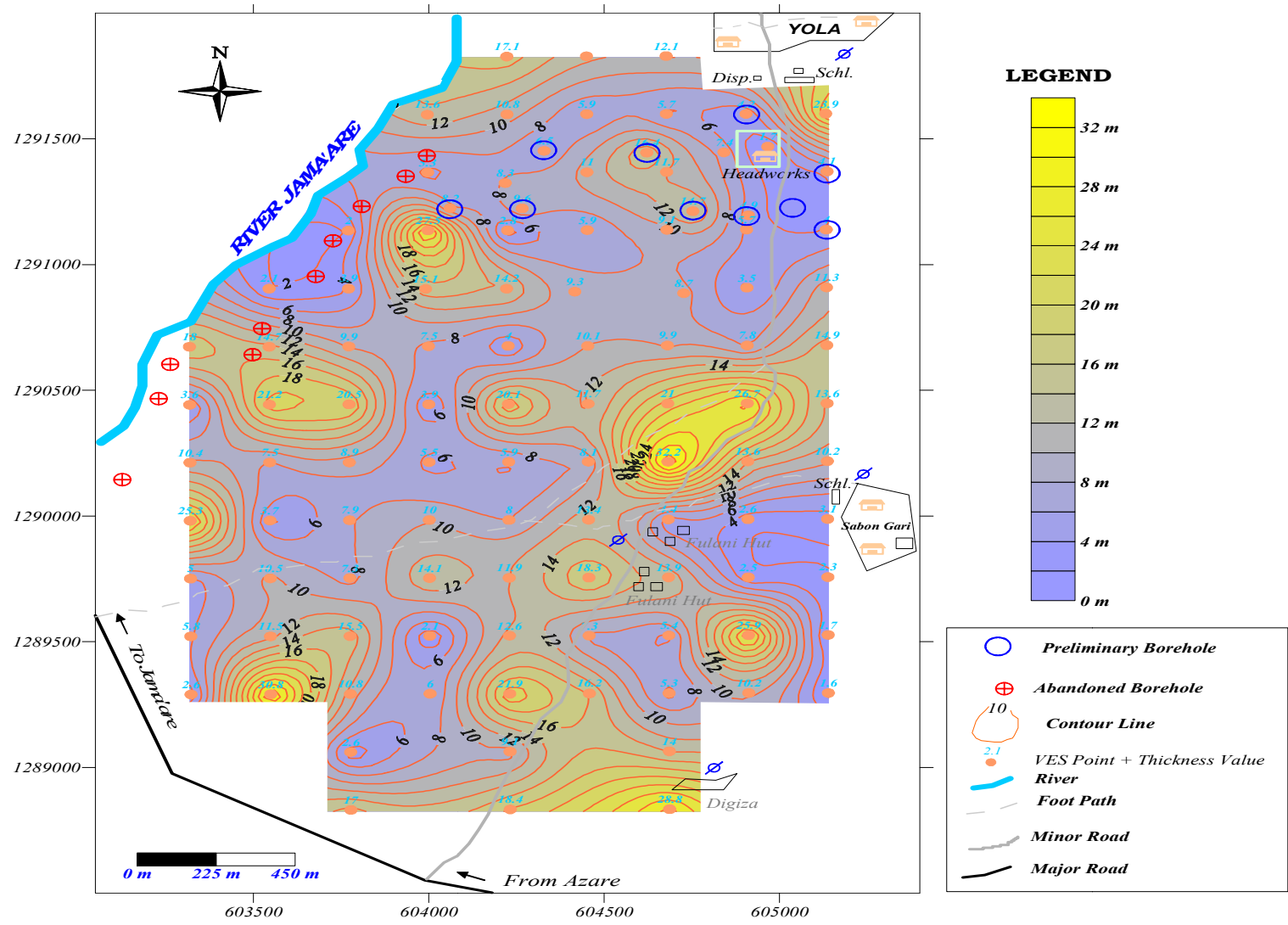

Fig. 6: Isopach Map of the Alluvium 
(b) Alluvium Layer: This layer is wet and usually water saturated. It ranges in composition from silt to fine, medium and coarse sands and constitutes the second layer with resistivity values that vary from 69 to 3079 ohm-m. The thickness of the alluvium generally varies from 1.6 to $32.2 \mathrm{~m}$ with the most frequently occurring thickness being in the $0-16 \mathrm{~m}$ range. The mean thickness is $10.6 \pm 7.1 \mathrm{~m}$ with a coefficient of variation of $66.7 \%$. The electrical resistivity characteristics of this layer are controlled by its degree of water saturation (Zohdy, 1980; Odusanya and Amadi, 1990). Figure 7 enables the spatial distribution and to a large extent, the vertical thickness of the alluvium to be evaluated. The linearly connected areas with thick alluvium may be indicative of network of ancient river channels within the floodplain. These areas also mirror a more recent NESW trend similar to the regional Tibesti-Cameroon trough.

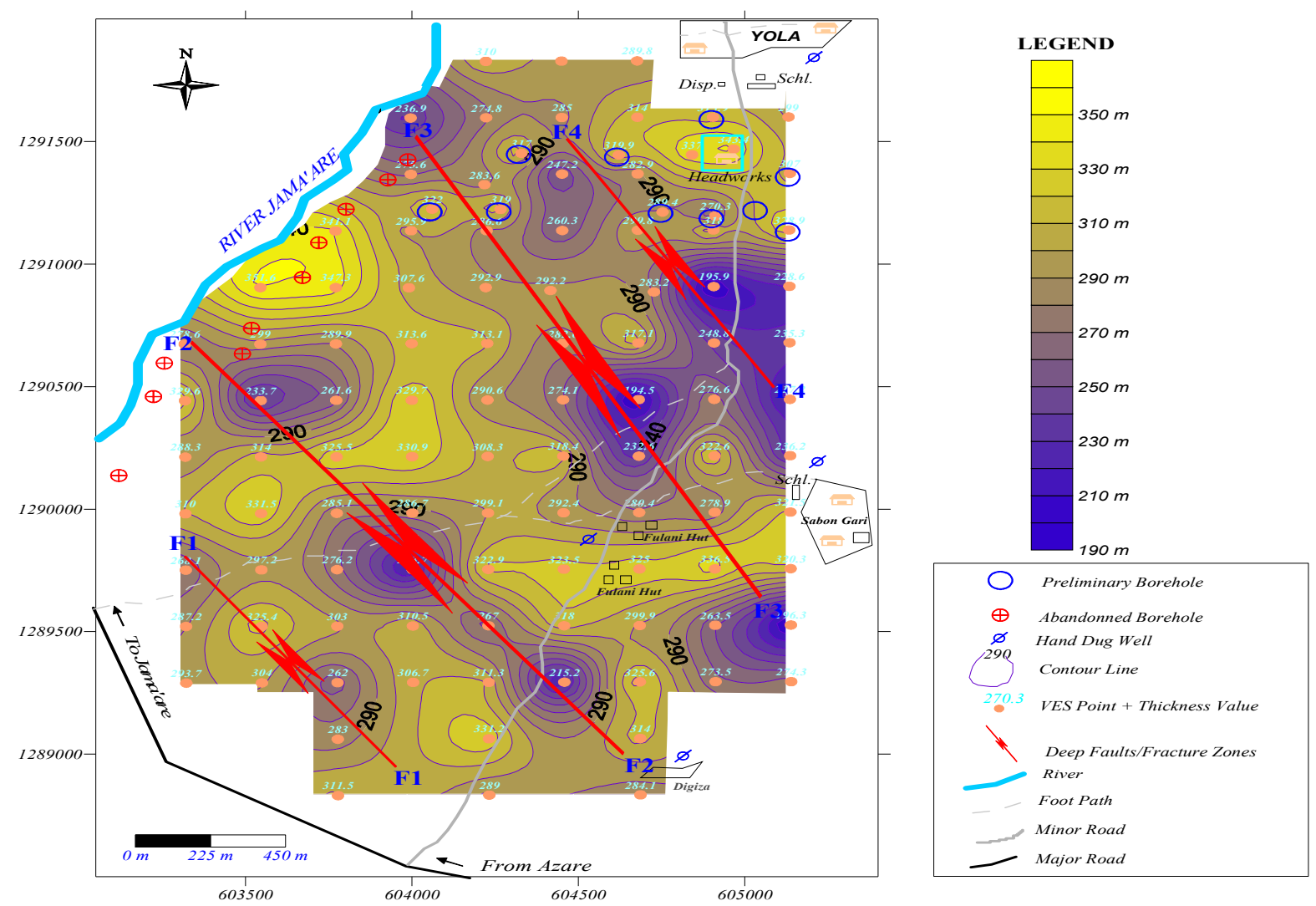

Fig. 7: Basement Relief Map of the Study Area

(c) Chad Formation/weathered basement: This is composed of varieties of clay materials i.e. reddish, milky and pinkish clay with coarse/gravelly or oxidized quartz/dirty sands intercalations. The layer resistivity values range from 11 to $140 \mathrm{ohm}-\mathrm{m}$, with coefficient of variation of $51.2 \%$ that indicates a near homogeneous unit. The most frequent occurring resistivity value is within $20-60 \mathrm{ohm}-\mathrm{m}$ range. Resistivity values less than between $20-60$ ohm-m range may suggest plastic clay while values greater than $100 \mathrm{ohm}-\mathrm{m}$ may be typical of sandy clay/sand. The thickness of this layer varies from 15.9-168.6 $\mathrm{m}$ with most frequent occurring thickness of between 20-80 m. The wide spectrum of thicknesses observed is due to the uneven topography of the basement bedrock. Figure 7 shows several discontinuous closures of high thicknesses typifying an uneven (undulating) basement bedrock relief. These closures however show three major parallel regional NW-SE trends. Although this horizon is significantly thick beneath several of the VES stations. its clavev nature judging from the relatively low layer resistivity, makes it more of an aquitard.

(d) Basement Bedrock: The fourth layer is the presumably fresh basement bedrock (see Fig. 4). The layer resistivity values are generally $>1000 \mathrm{ohm}-\mathrm{m}$ and in most cases infinite. The overburden thickness or depth to basement bedrock varies from 18.4 to $175.5 \mathrm{~m}$ with a mean value of $78.1 \pm 34.5 \mathrm{~m}$ and a coefficient of variation of $44.1 \%$. The most frequently occurring thicknesses vary from $40-100 \mathrm{~m}$.

The bedrock elevations vary between 190 and $350 \mathrm{~m}$ signifying an uneven relief of the basement bedrock. The basement depressions correlate approximately along four parallel regional NW-SE trends. These linearly correlated depressions may be indicative of deep seated faults. The hydrogeological significance of the basement bedrock relief was recognized by Olorunfemi and Okhue. 1992: Dan - Hassan and 
Olorunfemi, 1999; Olorunfemi et al., 1999; Bala and lke, 2001. Basement troughs are usually identified as groundwater collecting centres, exception to this was recorded in this sedimentary/basement transition area where basement troughs are filled with a complex variation of facies changes mainly argillaceous clayey Chad Formation. The formation grades into the basal clayey weathered basement layer with relatively low resistivity values that averaged about $40 \mathrm{ohm}-\mathrm{m}$. The layer matrix is appreciably clayey constituting an impermeable block with tendency for limited or low groundwater yielding capacity, in spite of its significant thicknesses (up to $175 \mathrm{~m}$ ) within axis of the deep basement depressions.

\section{CONCLUSION}

Four subsurface geologic layers were identified from the geoelectric sequences. These include a topsoil of variable moisture, alluvial sand, Chad Formation/clayey weathered column and basement bedrock. The layer resistivity and thickness ranges are 5 - 5706, 69 - 3079, $11-140$ and 994- >1000 (infinity) ohm-m and $0.4-9.3,1.6-32.2,15.9-168.6$ and depth to bedrock of 18.4 to $175.5 \mathrm{~m}$ respectively. The variation in the overburden thickness pattern mirrors the irregular geometry of the basement interface in several places. The linearly connected areas with thick overburden (along axis of the basement depressions) may have imaged a network of suspected parallel approximately NW-SE trending deep faults within the basement bedrock. The bedrock elevations vary between 190 and $350 \mathrm{~m}$ a.s.l. signifying a thickness pattern that is generally non-uniform or an uneven relief of bedrock ridges and depressions. Both the isopach maps of the topsoil and alluvial sand mirror a more recent NE-SW trend that correlated with the Tibesti-Cameroon trough.

However, the recent and shallow NE-SW structural trend and similar trend within the floodplain region are adjudged significant to future groundwater resource development, with depthsnot greater than $35 \mathrm{~m}$ as optimum for excellent contribution to the volume of the underground storagein the study area.

\section{ACKNOWLEDGEMENT}

The management of Aim Consultants, Lagos is appreciated for financing and providing logistic support for the data acquisition. Also, Professor M. O. Olorunfemi is acknowledged for editorial suggestions and Late Dr. I. A. Idornegie is acknowledged for his field assistance.

\section{REFERENCES}

Ako, B. D and Olorunfemi, M. O., 1989. Geoelectric survey for groundwater inthe Newer Basalts of Vom, Plateau State. Journal of Mining and Geology. 25, 247-250.

Bala, A. E and Ike, E. C., 2001. The aquifer of the Crystalline Basement rocks in Gusua area, Northwestern Nigeria. Journal of Mining and Geol., 37, (2): 177-184.

Carter, J. D., Barber W., Tait, E. A and Jones, G. D., 1963. The Geology of part of Adamawa, Bauchi and
Bornu Provinces in North Eastern Nigeria. Explanation on 1:250,000 sheets Nos. 25, 37 and 47. Geological Survey Bulletin No 30.

Dan-Hassan, M. A and Olorunfemi, M. O., 1999. Hydrogeological investigation of a Basement Terrain in the North-Central part of KadunaState, Nigerian Journal of Min. and Geol., 35, (2): 189-206.

F. S. N., 1978. National Atlas. Federal Survey of Nigeria, $1^{\text {st }}$ edition, Federal Surveys of Nigeria,. Pp. 5$11,136$.

Furon, R., 1963. The Geology of Africa. Oliver and Boyd, Edinburgh and London. 377.

Matheis, G., 1989. Short review of the geology of the Chad Basin in Nigeria In Geology of Nigeria. (Kogbe, C. A.Ed.) Rock view International, Jos. Nig. Pp 341-346.

Medeiros, W. E and de Lima, O. A. L., 1989. A geoelectrical investigation for groundwater in Crystalline terrains of Central Bahia, Brazil. In Groundwater. Vol. 28, (4): 518-523.

Mon, R and Vergara, G., 1987. The geothermal area of the eastern border of the Andes of north Argentina at Tucuma's Province. Bull. Internat. Assoc. Engr. Geologists. Vol.35: Pp. 87-92.

Odusanya, B. O and Amadi U. M. P., 1990. An empirical resistivity model for predicting shallow groundwater occurrence in the Basement Complex. Water Resources. Journal of Nigerian Association of Hydrogeologist. 2, 77-87.

Olayinka. A. I and Olorunfemi, M. O., 1992. Determination of geoelectrical characteristics in Okene area and implications for Borehole siting Journal of Mining and Geology. 28, (2): 403412.

Olorunfemi, M. O and Fasuyi, S. A., 1993. Aquifer types and the geoelectric/hydrogeologic characteristics of part of the central basement terrain of Nigeria (Niger State). Journal of African Earth Sciences. 16, Pp. 309-317.

Olorunfemi, M. O., Ojo, J. S and Akintunde, M. O., 1999. Hydrogeophysical evaluation of the groundwater potentials of the Akure metropolis, Journal of Mining and Geology, 35, (2): 207-228.

Olorunfemi, M. O and Okhue, E. T., 1992. Hydrogeologic and geologic significance of a geoelectric survey at Ile-lfe, Nigeria. Journal of Mining and Geology. 28, (2): 221-229.

Omosuyi, G. O., Ojo, J. S and Enikanselu, P. A., 2003. Geophysical investigation for groundwater around Obanla-Obakekere in Akure area within the Basement Complex of Southwestern Nigerian Journal of Mining and Geology.149151 
Schoeneich, K and Askira, M. T., 1990. Water resources of the Lake Chad Basin, Nigeria Journal of Nigerian Association of Hydrogeologists, Pp.56-64.

Seaton, W. J and Burbey, T. J., 2000. Aquifer characterization in the Blue-Ridge physiographic province using resistivity profile and borehole geophysics; geologic analysis. J. Environ. Eng. Geophysics, 5, Pp. 45-58
Zohdy, A. A. R., 1980. Electrical methods. In application of surface geophysics to groundwater investigations (Techniques of water resources investigations of the United States Geological Survey), Bk. 2, Ch. D1, 26-27. 